\title{
KARAKTERISTIK ARANG KULIT BUAH KAKAO YANG DIHASILKAN DARI BERBAGAI KONDISI PIROLISIS
}

\author{
The Characteristics of Cocoa Pod Husk Charcoal Produced in Various Pyrolysis \\ Conditions
}

\author{
Justus Elisa Loppies \\ Balai Besar Industri Hasil Perkebunan \\ Jl. Prof. Dr. Abdurahman Basalamah No. 28, Makassar \\ Pos-el : justusloppies@gmail.com
}

(Artikel diterima 2 November 2016; direvisi 30 November 2016; disetujui 5 Desember 2016)

\begin{abstract}
The importance of charcoal characteristics is related to its functions and purposes. Charcoal characteristics are determined by main components of the constituent materials, techniques, and pyrolysis conditions. This study aims to determine the characteristics of cocoa pod husk charcoal. The method used to produce charcoal is carbonization (pyrolysis) process on various conditions. The observed parameters were temperature and duration of pyrolysis process which is adjusted to obtain charcoal's maximum quality. Determining parameters of charcoal's characteristics is caloric value, fixed carbon, volatile, water content, and ash. The research shows that to obtain high quality charcoal, $4-5 \mathrm{~kg}$ cocoa pod husk is processed in $350^{\circ} \mathrm{C}$ during 2 hours. The charcoal's quality and characteristics processed in $350^{\circ} \mathrm{C}$ gain optimum caloric value $6,500-7,600 \mathrm{kcal} / \mathrm{kg}$, total carbon $42.57-45.53 \%$, volatile matter $30.14-32.98 \%$, ash content $16.21-16.22 \%$, and water content $6.25-8.44 \%$.
\end{abstract}

Keywords: charcoal, characteristics, cocoa pod husks, pyrolysis

Ringkasan. Pentingnya karakteristik arang berhubungan dengan fungsi dan peruntukkannya. Karakteristik arang ditentukan oleh komponen utama penyusun bahan baku, teknik dan kondisi pirolisis. Penelitian ini bertujuan untuk menentukan karakteristik arang dari kulit buah kakao. Metode yang digunakan untuk mendapatkan arang adalah karbonisasi (pirolisis) pada berbagai kondisi. Kondisi yang diamati meliputi Suhu dan waktu pirolisis disesuaikan dengan peruntukan kualitas arang. Parameter penentu karakteristik arang meliputi; nilai kalor, fixed carbon, volatile, kadar air dan kadar abu. Hasil penelitian menunjukkan bahwa untuk mendapatkan arang yang berkualitas adalah pada suhu $350^{\circ} \mathrm{C}$ selama 2 jam dari bobot bahan baku kulit buah kakao 4 - $5 \mathrm{~kg}$. Kualitas dan karakteristik arang yang diperoleh pada suhu $350^{\circ} \mathrm{C}$ memiliki nilai kalor optimum sebesar 6.500 -. $7.600 \mathrm{kcal} / \mathrm{kg}$, total karbon 42,57 - 45,53\%, volatile matter $30,14-32,98 \%$, kadar abu 16,21 - 16,22 \%, dan kadar air 6,25 - 8,44\%.

Kata kunci: arang, karakteristik, kulit buah kakao, pirolisis

\section{PENDAHULUAN}

Arang merupakan residu karbon tidak murni yang dihasilkan dengan proses pembakaran tidak sempurna terhadap hewan atau tumbuhan. Umumnya arang mengandung karbon, berbentuk padat dan berpori dimana sebagian porinya masih tertutup oleh hydrogen, tar dan senyawa organic lainnya seperti abu, air, nitrogen dan sulfur (Sudrajat dan Soleh, 1994 di dalam Agus Triono, 2006). Arang diketahui memiliki prospek pengembangan dan penggunaan yang sangat luas sebagai bahan baku industri. Manfaat dan Penggunaan arang tidak hanya sebagai bahan bakar, deodorizers (pengilang bau) dan penyaring tetapi telah dikembangkan lebih luas menjadi bahan yang dapat berfungsi sebagai penghasil energy (bateray, panel surya), media seni rupa, bahan pengisi, peawarna, dan lain-lain.

Sumber-sumber penghasil arang dapat berasal dari limbah partanian berupa kulit buah, kulit batang, batok/tempurung, sekam, kayu dan limbah industri seperti sisa olahan kayu dan produk sampingan lainnya.

Pada industri pengolahan buah kakao, kulitkakao merupakan limbah yangjumlahnya sangat banyak. Terdapat sekitar $70 \%$ kulit buah kakao (berat basah) dihasilkan dari satu kilogram buah kakao (Adzimah, 2010).

Pada umumnya limbah kulit buah kakao hanya dimanfaatkan sebagai bahan bakar (subtitusi kayu bakar/dibakar secara 
langsung), pakan ternak, atau dibiarkan membusuk sebagai kompos.

Kulit buah kakao berpotensi untuk dijadikan arang karena mengandung bahanbahan penyusunnya yang cukup tinggi yaitu lignin 60,67\%, selulosa (holoselulosa) 36, 47 $\%$ dan hemiselulosa 18,90 \% (Wijawa, 2014). Sedangkan penggunaan metode pirolisis dalam proses pengarangan berhubungan dengan penggunaan suhu tinggi dalam keadaan sedikit atau tanpa oksigen untuk mendapatkan arang yang berkualitas

Pirolisis adalah dekomposisi thermal material organik melalui proses pemanasan dengan sedikit atau tanpa kehadiran oksigen atau reagen lainnya, dimana material mentah akan mengalami pemecahan struktur kimia menjadi gas (https:Wikipedia. org /wiki/pirolisis. Diakses pada tanggal 06 Desember 2016). Pirolisis berlangsung pada kisaran suhu $200^{\circ}-600^{\circ} \mathrm{C}$. Demirbas (2005) melaporkan bahwa pirolisis umumnya berlangsung pada suhu diatas 300 OC dalam waktu $4-7$ jam, namun keadaan ini sangat bergantung pada bahan bak dan cara pembuatannya. Pirolisis menghasilkan produk gas, cair dan padat bergantung pada prosesnya ( Danarto, 2010). Jadi pirolisis juga merupakan proses pengarangan dengan menggunakan udara terbatas pada suatu sistim tertutup degan panas tinggi.

Proses pirolisis berlangsung dalam empat tahap yaitu : 1) Tahap penguapan air dari bahan yang terjadi pada suhu 100 - $120{ }^{\circ} \mathrm{C}$, kemudian dilanjutkan dengan penguraian celulosa sampai mencapai suhu $260{ }^{\circ} \mathrm{C}$, 2) Tahap intensif penguraian celulosa yang berlangsung pada suhu 260 $310^{\circ} \mathrm{C}$, 3) Tahapan penguraian lignin yang menghasilkan tar, berlangsung pada suhu $310-500{ }^{\circ} \mathrm{C}$, 4) Tahapan pemurnian arang, yang berlangsung pada suhu $500-1000{ }^{\circ} \mathrm{C}$.

Pengarangan atau karbonisasi merupakan pirolisis ekstrim yang hanya meninggalkan karbon sebagai residu. Fungsi utama karbonisasi adalah untuk meningkatkan nilia kalor, karena selama proses karbonisasi terjadi pelepasan kandungan air dan sejumlah senyawa volatile (https:Wikipedia.org/wiki/pirolisis. Diakses pada tanggal 06 Desember 2016).
Karakteristik arang ditentukan oleh jenis bahan, komponen utama penyusun bahan baku yang akan dipirolisis dan metode pirolisis.

Produk karbon sebagai hasil proses pirolisis terkadang memiliki karakteristik yang tidak sesuai dengan peruntukannya sehingga perlu proses optimasi atau diperlukan proses lanjutan untuk meningkatkan kualitasnya.

Kualitas dan peruntukan arang dapat ditingkatkan melalui proses aktivasi dan perubahan sifat atau strukturnya untuk mendapatkan karakteristik arang dengan manfaat yang lebih luas. Beberapa produk industri telah mengembangkan arang menjadi bahan energy, farmasi, kosmetik, namun secara spesifik penggunaan arang sebagai bahan baku industri tersebut tidak secara langsung dimanfaatkan tetapi harus melalui proses pengolahan yang akurat dan seleksi yang ketat sehingga diperoleh bahan arang yang memiliki sifat dan karaktristik sesuai dengan peruntukannya.

Arang yang berkualitas menurut Pari et al (2006) dapat ditentukan dengan syaratsyarat sebagai berikut : 1) Cukup keras dan tidak mudah hancur, 2) mempunyai kandungan arang (fixed carbon) lebih dari 75 $\%$, 3) kadar abu $5 \%$, 4) kadar air maks.15 $\%$, 5) Kadar zat menguap maks. $15 \%$, 6 ) Tidak tercemar oleh unsur-unsur yang membahayakan atau kotoran.

Nurida et al (2009) melaporkan bahwa arang kulit buah kakao memiliki beberapa keunggulan antara lain : kandungan $\mathrm{N}$, $\mathrm{P}, \mathrm{K}, \mathrm{Ca}, \mathrm{Mg}, \mathrm{C}$-organik dan kemampuan meretensi air lebih tinggi dibanding arang batok kelapa, sehingga jenis arang ini diarahkan penggunaannya sebagai bahan pembenah tanah. Sifat-sifat lain yang terkait dengan peruntukan arang kulit kakao sebagai bahan energy, farmasi dan kosmetik atau penggunaan lainnya tidak dilaporkan pada penelitian ini. Terkait fungsi dan peruntukkan arang kulit buah kakao sebagai produk industri, perlu diketahui karakteristik awal yang meliputi: nilai kalor, volatile matter, sulfur dan oksigen. Melalui penelitian ini, limbah kulit buah kakao akan dimanfaatkan dan diolah menjadi arang secara pirolisis. 
Penelitian ini bertujuan untuk menentukan kualitas dan karakteristik arang yang dihasilkan dari kulit buah kakao, dengan harapan bahwa data karakteristik dan metode pirolisis ini dapat dijadikan acuan untuk menetapkan arah pengembangan sediaan arang menjadi produk yang bernilai dan sesuai dengan peruntukannya.

\section{METODOLOGI}

\section{Bahan dan Alat}

Bahan-bahan yang digunakan dalam peneltian ini antara lain: kulit buah kakao yang diperoleh dari kelompok tani di Kabupaten Luwu Utara, Sulawesi Selatan, $\mathrm{Na}_{2} \mathrm{CO}_{3}$, metil merah, $\mathrm{NaOH}, \mathrm{KOH}$, aquadest. Peralatan yang digunakan antara lain : alat pirolisis yang rancang untuk pembuatan arang dan asap cair (Gambar 1), mesin pencacah kulit buah kakao, dan neraca kapasitas $5 \mathrm{~kg}$. Peralatan uji yang terdiri dari: GC-MS, alat uji proximat dan ultimat arang dan spectrophotometer.

\section{Pelaksanaan Penelitian}

Tempat Pelaksanaan

Penyiapan bahan, peralatan dan proses pembuatan arang dilaksanakan di Balai Besar Industri Hasil Perkebunan (BBIHP) Makassar. Sedangkan untuk pengujian produk, sebahagian dilaksanakan di laboratorium BBIHP, dan sebahagian lagi dilaksanakan di laboratorium Sucofindo Makassar, dan laboratorium Sucofindo Cibitung-Bekasi.

\section{Penyiapan bahan baku dan Proses Pirolisis}

Bahan baku berupa kulit buah kakao segar dicacah dengan ukuran tertentu kemudian dijemur menggunakan panas matahari hingga mencapai kadar air $6-7$ $\%$. Kulit buah kakao kemudian di timbang sebanyak $5 \mathrm{~kg}$ dan dimasukkan ke dalam kolom pirolisis. Kolom pirolisis ditutup dan pembakaran dimulai dari bagian dasar kolom. Pembakaran secara pirolisis berlangsung kontinyu dalam kondisi sedikit atau tanpa oksigen. Proses pirolisis dilakukan sesuai perlakuan yang terdiri dari: suhu pirolisis (1 jam, 2 jam, 3 jam), dan waktu pirolisis $\left(200{ }^{\circ} \mathrm{C}, 250{ }^{\circ} \mathrm{C}, 300{ }^{\circ} \mathrm{C}, 350{ }^{\circ} \mathrm{C}\right)$. Selama pembakaran, suhu dan waktu pirolisis dikontrol agar konsisten sesuai perlakuan. Arang yang diperoleh kemudian didinginkan dalam kondisi vakum untuk mencegah terjadinya pengabuan.

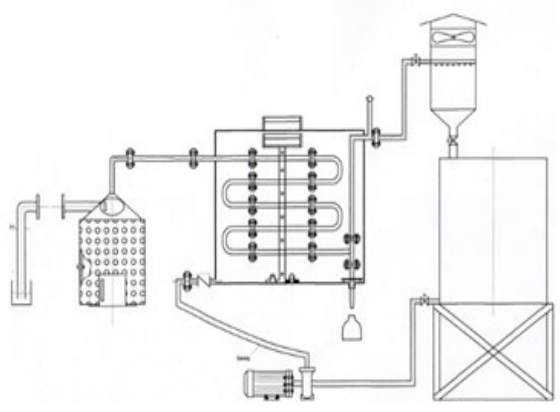

Gambar 1. Instalasi unit pirolisis untuk pembuatan arang kulit buah kakao

\section{Pengujian}

Penentuan karakteristik arang dilakukan secara proximat melalui beberapa parameter uji antara lain; fixed carbon (ASTM D-3172-73), nilai kalor (ASTM D-2015-77), volatile matters (ASTM D-3175-02), kadar abu (ASTM D-3174-04) dan kadar air (ASTM D-3173-03).

\section{HASIL DAN PEMBAHASAN}

Uji proximat dari hasil pengarangan kulit buah kakao pada suhu dan waktu yang berbeda menunjukkan perbedaan terhadap kadar karbon, nilai kalor, volatile maters, kadar abu, dan kadar air

Kadar karbon dan nitrogen cenderung meningkat dari suhu $200{ }^{\circ} \mathrm{C}$ ke suhu $250{ }^{\circ} \mathrm{C}$ namun menurun setelah suhu pembakaran dinaikan ke $300{ }^{\circ} \mathrm{C}$ dan 250 ${ }^{\circ} \mathrm{C}$. Kadar Hidrogen dan oksigen mengalami peningkatan sejalan dengan bertambahnya suhu pembakaran tetapi kadar abu (ash) dan sulfur mengalami pola perubahan secara kubik dimana meningkat pada suhu $200{ }^{\circ} \mathrm{C}$ dan $300{ }^{\circ} \mathrm{C}$ tetapi menurun pada suhu $350{ }^{\circ} \mathrm{C}$.

Secara umum, pengarangan yang baik untuk bahan kulit buah kakao terjadi pada suhu $300{ }^{\circ} \mathrm{C}-350{ }^{\circ} \mathrm{C}$, dimana pada suhu ini diperoleh kadar karbon, hydrogen dan nitrogen tertinggi dengan kadar abu yang rendah (Gambar ). 


\section{Fixed Carbon}

Fixed carbon diperoleh dari $100 \%$ dikurangi dengan kadar air, kadar abu, kadar volatile matter. Biomassa dengan berat jenis tinggi membutuhkan waktu lama untuk proses pembakaran. Dilaporkan oleh Nurhayati dan Hartoyo (1976),

Kadar "fixed carbon" yang tinggi menunjukkan bahwa produk arang akan membutuhkan waktu pembakaran yang lebih lama dalam aplikasinya.

Hasil pengujian menunjukkan bahwa fixed carbon tertinggi berkisar antara 42,57 $\%$ sampai $45,53 \%$ diperoleh pada perlakuan suhu $350{ }^{\circ} \mathrm{C}$ selama pembakaan 2 sampai 3 jam dibanding dengan perlakukan lainnya (Gambar 2). Hal ini menunjukkan bahwa pada tahap awal belum terjadi proses pirolisis secara sempurna dimana sebagian batok kulit buah kakao belum menjadi arang. Sedangkan pada suhu yang sama dengan waktu pembakaran yang lebih lama (3 jam) menyebabkan terjadinya "over pirolisis" sehingga sebagian biomassa berubah menjadi abu.

"over pirolisis" berubungan dengan berat jenis (BJ) material, suhu dan waktu pirolisis. Material dengan BJ rendah (seperti kulit buah kakao) memerlukan waktu yang lebih cepat dalam proses pengarangan. Tanaka (1963) melaporkan bahwa pembakaran dengan temperature tinggi akan menurunkan produksi biochar (arang) tetapi meningkatkan fixed carbon.

Fixed Carbon (\%)

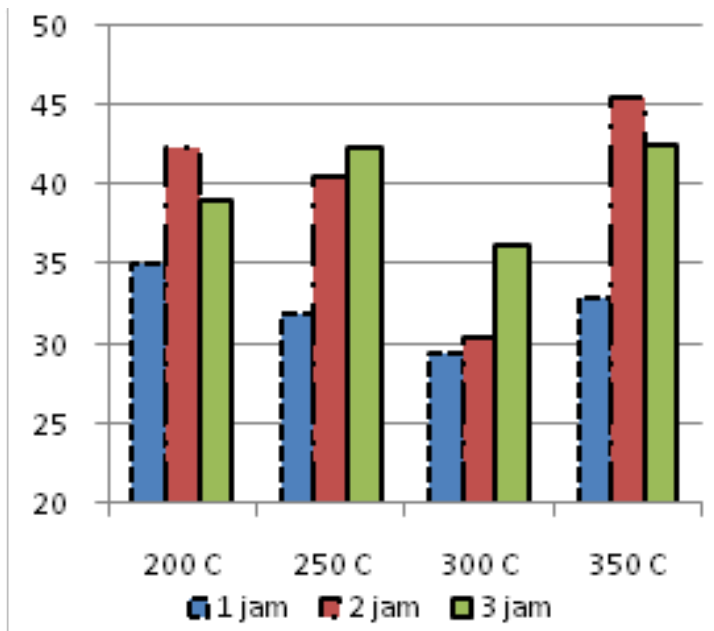

Gambar 2. Kadar "fixed carbon" arang kulit buah kakao dari berbagai perlakukan pirolisis

\section{Nilai Kalor}

Nilai kalor merupakan panas yang dilepaskan dari suatu proses pembakaran terhadap sejumlah unit bahan bakar (massa) dalam bentuk abu (ash), gas $\mathrm{CO}_{2}, \mathrm{SO}_{2}$, Nitrogen dan air, tidak termasuk uap (vapor). Umumnya nilai kalor dijadikan indicator utama untuk menentukan kualitas suatu bahan bakar. Nilai kalor berhubungan dengan kadar karbon dan kadar abu, dimana kadar kadar karbon yang tinggi memberikan efek pebakaran dan efek nyala yang lebih lama. Sedangkan kadar abu yang tinggi dapat menurunkan nilai kalor.

Hasil pengujian menunjukkan bahwa nilai kalor meningkat pada suhu pembakaran $250^{\circ} \mathrm{C}$ sampai $300^{\circ} \mathrm{C}$ dan menurun pada suhu $350{ }^{\circ} \mathrm{C}$. Rata-rata nilai kalor tertinggi untuk arang kulit buah kakao berada pada kisaran 2704.4 sampai $2812 \mathrm{kcal} / \mathrm{kg}$ diperoleh pada suhu $350{ }^{\circ} \mathrm{C}$ selama pembakaan 2 sampai 3 jam (Gambar 3), dimana nilai ini masih jauh berada dibawah nilia kalor batok kelapa yaitu 6500 - $7600 \mathrm{kcal} / \mathrm{kg}$. Dilaporkan dalam hasil penelitian Patabang (2011) bahwa nilai kalor kulit buah kakao dapat mencapai 6308,207 $\mathrm{kcal} / \mathrm{kg}$ setelah dikembangkan menjadi briket.

Nilai Kalor (kcal/kg)

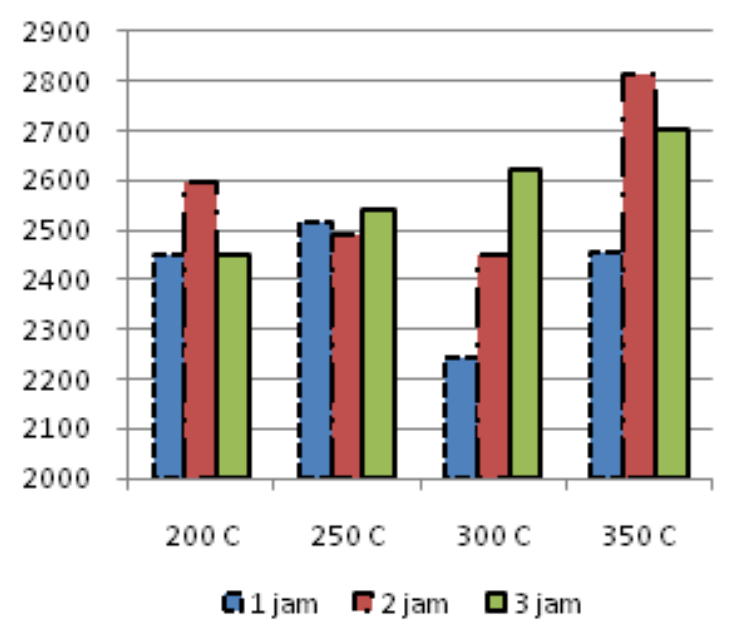

Gambar 3. Nilai kalor arang kulit buah kakao dari berbagai perlakukan pirolisis

\section{Volatile Matters (VM)}

Kandungan volatile matters (VM) berperan dalam memberikan kemampuan nyala dari suatu biomassa. Suatu biomassa jika dipanaskan sampai mencapai 
suhu tertentu akan menimbulkan bara (combustibility) dan pengapian atau nyala (ignitability) karena pada kondisi ini terjadi pelepasan volatile matters.

Hasil pengujian menunjukkan bahwa pirolisis dengan suhu $200{ }^{\circ} \mathrm{C}$ sampai 300 ${ }^{\circ} \mathrm{C}$ selama 1 - 2 jam menyebabkan terjadi kenaikan kadar volatile matters (VM), namun pada suhu $350{ }^{\circ} \mathrm{C}$ mulai terjadi penurunan kadar VM (Gambar 4). Rata-rata kadar VM kulit buah kakao tertinggi adalah 43,13 sampai $43,37 \%$ pada pirolisis $300^{\circ} \mathrm{C}$ selama 1 - 2 jam dan terendah berada pada kisaran $30,14 \%$ sampai $32,98 \%$ diperoleh pada suhu $350{ }^{\circ} \mathrm{C}$ selama pembakaran $2-3$ jam (Gambar 4).

Pirolisis dengan suhu $350 \quad{ }^{\circ} \mathrm{C}$ memungkinkan sebagian besar senyawa volatile terlepas atau terbuang sehingga bersampak pada penurunan nilai VM.

Tingginya kadar VM menunjukkan masih terdapat senyawa non karbon yang terikat pada arang. Senyawa non karbon ini dapat menutupi permukaan atau pori-pori arang sehingga berdampak pada daya serap arang (Pari et al, 2006).

Volatile Matter (\%)

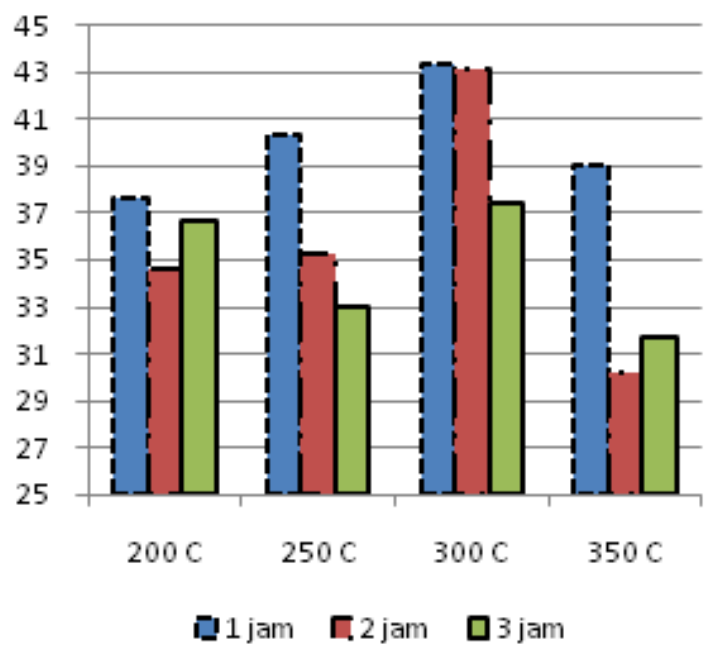

Gambar 4. Kadar volatile matter arang kulit buah kakao dari berbagai perlakukan pirolisis

\section{Kadar Abu}

Kadar abu merupakan sisa proses pembakaran berupa mineral yang tidak mengandung unsur karbon.
Kadar abu berhubungan dengan nilai kalor dan kadar karbon, dimana kadar abu yang tinggi menyebabkan penurunan nilai kalor dan kadar karbon. Rendahnya nilai kalor dan kadar karbon akan berdampak pada penurunan daya serap dan kemampuan nyala dari arang.

Hasil penelitian menunjukkan bahwa variasi kadar abu dipengaruhi oleh suhu dan waktu pirolisis.

Kadar abu arang kulit buah kakao berkisarantara 14,86\% sampai $23,25 \%$. Pada suhu pirolisis $200-300{ }^{\circ} \mathrm{C}$ selama 1 - 2 jam terjadi peningkatan kadar abu dan kemudian menurun pada jam ke-3. Sedangkan pada suhu $350{ }^{\circ} \mathrm{C}$ terjadi penurunan drastis kadar abu selama pembakaran $1-3$ jam.

Meningkatnya kadar abu diduga berhubungan dengan pembentukan garamgaram mineral dan partikel lain sebagai akibat oksidasi karbon selama pirolisis. Sumber lain sebagai penghasil kadar abu adalah kandungan silikat kulit buah kakao sekitar 0,47 \% (Wijaya, 2014).

Kondisi ideal untuk menghasilkan arang kulit buah kakao dengan kadar abu terendah adalah pada suhu pembakaran $350{ }^{\circ} \mathrm{C}$ selama 2- 3 jam dengan kadar abu berkisasr antara 16,21 - 16,22 \% (Gambar 5).

Kadar Abu (\%)

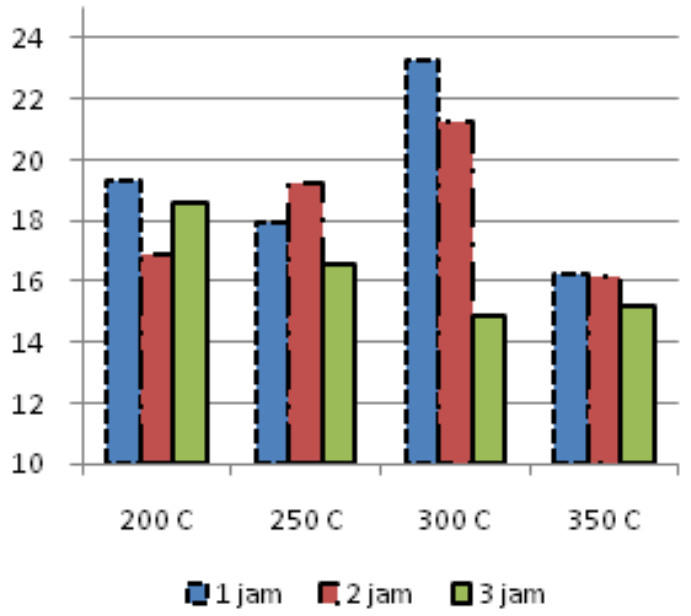

Gambar 5 . Kadar abu arang kulit buah kakao dari berbagai perlakukan pirolisis

\section{Kadar Air}

Kadar air dapat mempengaruhi daya serap gas maupun cairan (Pari, 1996). Kadar 
air yang tinggi dapat menurunkan kualitas arang, terutama berpengaruh terhadap nilia kalor dimana arang dengan kadar air tinggi dapat menurunkan nilai kalor sehingga arang akan sulit menyala. Proses pengarangan pada berbagai konsisi pirolisis dapat mempengaruhi kadar air produk arang yang dihasilkan (Gambar 6)

Hasil pengujian menunjukkan bahwa pada awal pembakaran 1 jam dengan suhu $200{ }^{\circ} \mathrm{C}-300{ }^{\circ} \mathrm{C}$, terjadi perubahan kadar air arang kulit buah kakao secara fluktuatif dan kemudian meningkat pada suhu $200{ }^{\circ} \mathrm{C}$ sampai $300{ }^{\circ} \mathrm{C}$ dengan waktu pirolisis 2 jam sampai 3 jam. Pada suhu $350{ }^{\circ} \mathrm{C}$ dengan waktu pembakaran $1-3$ jam mulai terjadi penurunan kadar air. Hal ini sejalan dengan nilai kalor yang dihasilkan dari kondisi suhu tersebut.

Rata-rata kadar air terbaik arang kulit buah kakao berkisar antara 6,25\% sampai $8,44 \%$ pada pirolisis suhu $350{ }^{\circ} \mathrm{C}$ dengan waktu 2 - 3 jam.

Peningkatan kadar air secara lambat selama proses pirolisis 2 sampai 3 jam pada suhu $200-300{ }^{\circ} \mathrm{C}$ berhubungan dengan kondisi semi vacuum (kurang atau tanpa oksigen) pada tangki pirolisis yang menyebabkan perlambatan proses penguapan dan pelepasan air ke luar tangki pirolisis. Proses penguapan mulai meningkat setelah suhu dinaikan menjadi $350{ }^{\circ} \mathrm{C}$.

Kadar air arang tidak selamanya stabil, disamping dipengaruhi oleh suhu dan waktu pirolisis juga dipengaruhi oleh penyimpanan, dimana pada kondisi lembab dapat menyebabkan terjadinya absorbsi uap air disekitar. Selain itu kadar air dapat menentukan kualitas nyala dari suatu arang. Hasil pengamatan kadar air arang kulit buah kakao menunjukkan nilai yang relevan dengan nilai kalor untuk menghasilkan pembakaran sempurna (Gambar 3 dan Gambar 6).

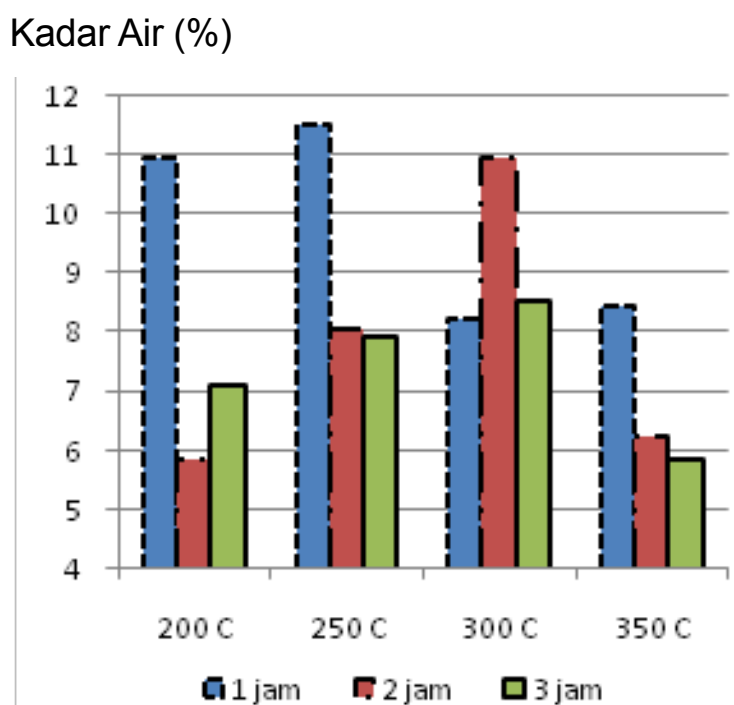

Gambar 6. Kadar air arang kulit buah kakao dari berbagai perlakukan pirolisis

\section{SIMPULAN DAN SARAN}

\section{Simpulan}

Hasil penelitian menunjukkan bahwa untuk mendapatkan arang kulit buah kao yang berkualitas adalah pada suhu $350{ }^{\circ} \mathrm{C}$ selama 2 - 3 jam dari bobot bahan baku kulit buah kakao 4 - $5 \mathrm{~kg}$.

Arang kulit buah kakao yang dihasilkan dari proses dipirolisis pada suhu $350{ }^{\circ} \mathrm{C}$ memiliki nilai kalor optimum sebesar 6.500 -. $7.600 \mathrm{kcal} / \mathrm{kg}$, total karbon $42,57-45,53 \%$, volatile matter $30,14-32,98 \%$, kadar abu $16,21-16,22 \%$ dan kadar air 6,25 - 8,44\%.

Produk arang yang diperoleh belum dipersyaratkan penggunaannya pada industri, namun Spesifikasinya dapat digunakan untuk pengembangan menjadi produk baru.

Proses pirolisis yang tidak terkontrol dapat menyebabkan kegagalan pembentukan arang kulit buah kakao.

\section{Saran}

Pengembangan arang kulit buah kakao menjadi produk baru dapat dilakukan melalui proses aktivasi atau dengan pirolisis pada tekanan dan suhu yang lebih tinggi dalam kondisi semi vacuum. 
Karakteristik arang yang diperoleh dapat dijadikan acuan untuk pengembangan menjadi bahan baku energy, farmasi dan kosmetik.

\section{DAFTAR PUSTAKA}

1. Darmadji, P. 2002. Optimasi Pemurnian Asap Cair dengan Metoda Redistilasi. Jurnal Teknologi dan Industri Pangan 13(3), 267-271.

2. Girrard, J.P. 1992. Smoking in Technology of Meat Products. Clermont Ferrand. Ellis Horwood, New York pp: 165:205.

3. Kollman, F. P. and Cote, W. A. 1984. Principles of Wood Science and Technology. Sprenger Verlag, New York.

4. Maga, J.A. 1988. Smoke in Food Processing. CRC Press, Inc. Boca Raton, Florida: 1-3, 131-138.

5. Nurida, N.L., A. Dariah, dan A, Rachman. 2009. Kualitas Limbah Pertanian sebagai Bahan Baku Pembenah Tanah Berupa Biochar untuk Rehabilitasi Lahan. Prosiding Seminar Nasional dan Dialog Sumberdaya Lahan Pertanian. Tahun 2008.

6. Ogawa, M. 20016. Carbon Sequestration by Carbonization of Biomass and
Forestation: Three Case Studies. P. 133 $-146$.

7. Pari, G. D. Hendra dan R.A. Pasaribu. 2006. Pengaruh Lama Waktu Aktivasi dan Konsentrasi Asam Fosfat terhadap Mutu Arang Kulit Kayu Acacia mangium. Jurnal Penelitian Hasil Hutan. 24 (1): 3336. Pusat litbang Hasil Hutan, Bogor.

8. Patabang, D. 2011. Studi Karakteristik Termal Briket Arang Kulit Buah Kakao. Jurnal Mekanikal, Vol. 2 No. 1: Januari 2011:23-31

9. Pszczola, D. E. 1995. Tour Higlights Production and Uses of Smoke Base Flavors. Food Tech. (49): 70-74.

10. Solichin, M. 2007. Penggunaan Asap Cair Deorub dalam Pengolahan RSS. Jurnal Penelitian Karet, Vol.25(1) : 1-12.

11. Tranggono, dkk. 1996. Identifikasi Asap cair dari berbagai jenis kayu dan tempurung kelapa. J. ilmu dan Tek. Pangan. Vol. 1(2) : 15-24.

12. Wijaya, M. 2014. Pemanfaatan Limbah Kakao sebagai Bahan Baku Produk Pangan. Prosiding Seminar Nasional Kimia dan Pendidkan Kimia VI. Jurusan Kimia FMIPA Univ. Negeri Makassar. ISBN: 979363174-0 